\title{
Notes on Antonina Mealybug of Korea (Hemiptera: Pseudococcidae)
}

\author{
Yong-Hyun Lee and Soo-Jung Suh*
}

Yeongnam Regional Office, National Plant Quarantine Service, Korea

\section{한국산 교리가루깍지벌레속의 재정리 (노린재목: 가루깍지벌레과)}

\author{
이용현 · 서수정* \\ 국립식물검역원 영남지원
}

\begin{abstract}
The legless mealybug, Antonina nakaharai Williams and Miller (Hemiptera: Pseudococcidae) is recorded from bamboos (Poaceae) in Korea. An identification key to adult females of three species of Antonina from the Korean Peninsula is also provided.
\end{abstract}

Key words: Hemiptera, Pseudococcidae, Antonina nakaharai Williams and Miller, Korea, bamboo

초 록: 한국의 대나무류에 다리가 퇴화한 꼬리가루깍지벌레속의 Antonina nakaharai Williams and Miller 대나무꼬리가루깍지벌레(신칭)가 발생함을 확인하고, 한반도에 분포하는 꼬리가루깍지벌레속 3종 동정에 필요한 검색표를 함께 정리하였다.

검색어: 노린재목, 가루깍지벌레과, Antonina nakaharai Williams and Miller, 한국, 대나무류

Species of the genus Antonina are legless mealybugs (Pseudococcidae) that are found on grasses including bamboo. Currently, the genus is comprised of 28 species and is known to occur in all of the zoogeographic regions of the world (Miller et al., 2010). Only two species, Antonina crawi Cockerell (A. crawii misspelling by Paik, 2000) and Antonina vera Borchsenius have been documented in the Korean Peninsula (Paik, 2000; Kwon et al., 2003). Borchsenius (1956) described $A$. vera from North Korea but this species has not yet been found in South Korea.

Herein, we report the occurrence of an additional species in the genus, Antonina nakaharai Williams and Miller, which was found on bamboo in this country. Williams and Miller (2002), after a thorough analysis of the Antonina crawi Cockerell complex, described the species and reported its presence in China, Japan, Russia, Hawaii and continental U.S.A. (probably introduced). Since then, it has been collected from Azerbaijan

*Comesponding author: suhsj97@korea.kr

Received November 4 2010; Revised March 16 2011; Accepted March 182011 and Georgia.

Listed below are records from Korea of this mealybug occurring on three species of bamboo-like grasses :

Poaceae: Arundinaria simonii (Gyeongsangnamdo: Eulsukdo, 13 adult females, on leaf sheath, 30-viii-2001 (Y.H. Lee)), Phyllostachys pubescens (Jeollanamdo: Damyang-gun, 6 adult females, on leaf sheath, 23-vii-2005 (S.J. Suh)), and Phyllostachys sp. (Gyeongsangbukdo: Sobo-myeon, 1 adult female, 5-vii-1999; Sangyeok-dong, 10 adult females, on leaf sheath, 13-vi-2001 (Y.H. Lee); Jeollanamdo: Yulpo-ri, 1 adult female, on leaf sheath, 15-v-2009 (S.J. Suh)).

According to labels on specimens of $A$. nakaharai from Japan and China examined for Williams and Miller's study (2002), this species had been collected in Japan and China in 1889 and 1941, respectively. Its hosts are native to China and have been grown in the southern regions of Asia, including Korea, for hundreds of years. In addition, other Antonina species, such as A. bambusae Khalid and Shafee from India, A. crawi Cockerell probably from Japan or China, and A. elongata Tang from China, are native to 

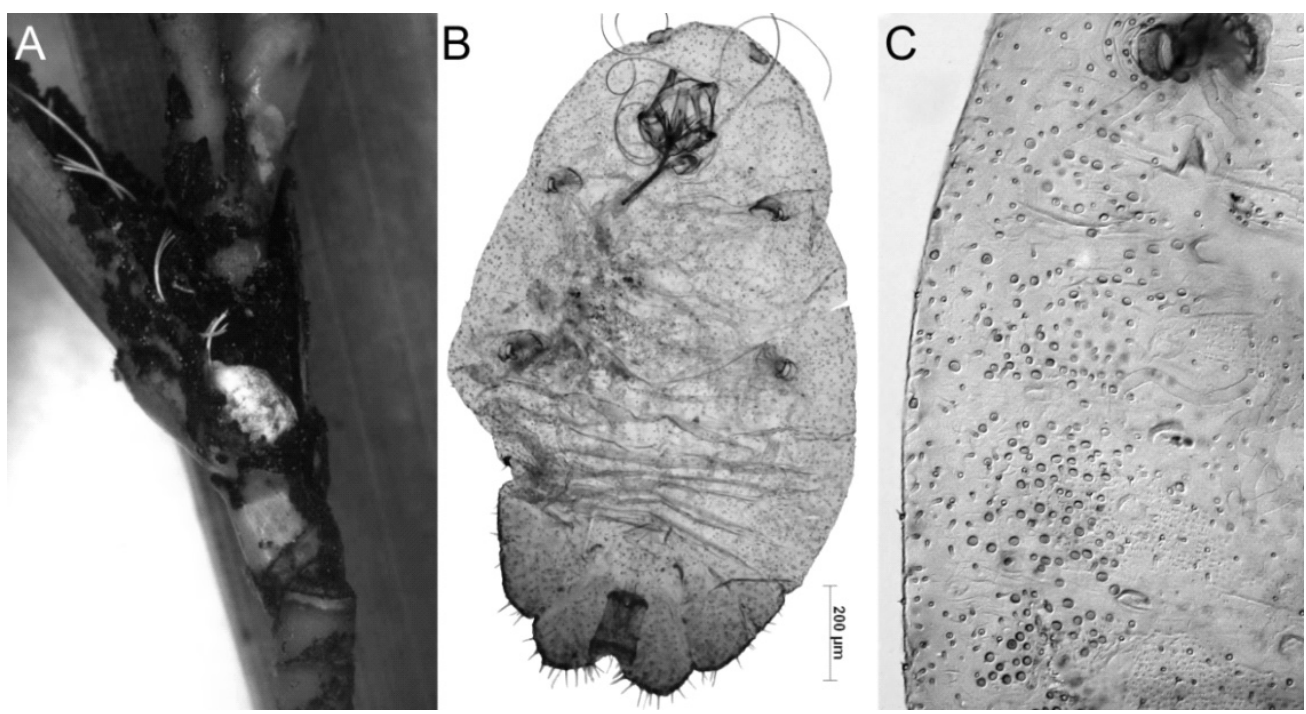

Fig. 1. Antonina nakaharaiWilliams and Miller: A. Adult female on bamboo, B. Slide mounted adult female, C. Ventral abdomen.

the Asia (Williams and Miller, 2002). We believe that $A$. nakaharai is probably native to East Asia and should not be considered as a species that has been accidently introduced into Korea.

Critical reexamination of the Antonina crawi Cockerell complex, by Williams and Miller (2002) showed that the complex is comprised of the following three, very similar species: $A$. crawi Cockerell, A. nakaharai Williams and Miller, and $A$ socialis Newstead, that primarily feed on bamboo and its relatives. Based upon the illustration of what was labeled as $A$. crawi Cockerell in Paik (1978), they stated that the specimen probably represented a misidentification of $A$. socialis Newstead. We consider the species Kwon et al. (2003) identified as A. crawi from Korea is probably to be a misidentification of $A$. nakaharai since the illustration of the species in Kwon's dissertation (2002), on which they based their paper, is not $A$. crawi but rather $A$. nakaharai. Further study will be required to determine with certainty, which species of Antonina exist in Korea.

Adult females of the three species of Antonina reported from Korea can be distinguished by the following key, which was modified from that of Williams and Miller (2002) and Danzig (1986).

1. Multilocular pores of uniform size present below the hind spiracles and body with differentiated pores $\cdot 2$

1b. Multilocular pores of two sizes present below the hind spiracles and body without differentiated pores

\section{A. vera Borchsenius}

2(1). Ventral abdominal multilocular pores abundant, with 6 or more pores on segment IV in area within the cluster of disc-like pores

\section{A. crawi Cockerell}

2b. Ventral abdominal multilocular pores abundant, with 5 or fewer pores on segment IV in area within the cluster of disc-like pore clusters

\section{A. nakaharai Williams and Miller (Fig. 1)}

\section{Acknowledgements}

I would like to thank Drs. Greg Evans and Douglass Miller (USDA/Animal and Plant Health Inspection, USA) for confirming the identification. I also thank Dr. Greg Evans for his useful editorial contributions to this manuscript. This research was supported by a grant from the National Plant Quarantine Service.

\section{Literature Cited}

Borchsenius, N.S. 1956. Notes on the Coccoidea of Korea. Entomologicheskoe Obozrenye 35: 671-679.

Danzig, E.M. 1986. Coccids of the Far-Eastern USSR (Homoptera: Coccinea). Phylogenetic analysis of coccids in the world fauna. 450 pp. Amerind Publishing Co., New Delhi, India.

Kwon, G.M. 2002. Taxonomic revision of the family Pseudococci- 
dae (Homoptera: Coccinea) in Korea. Doctor's thesis. 212pp. The graduate school of Kangwon National University.

Kwon, G.M., E. Danzig, and K.T. Park. 2003. Taxonomic notes of the family Pseudococcidae (Sternorrhyncha) in Korea. I. Tribes Phenacoccini, Rhizoecini, and Sphaerococcini. Insecta Koreana 20(1): 103-124.

Miller, D.R., Y. Ben-Dov and G.A.C. Gibson. 2010. ScaleNet(webpage) http://www.sel.barc.usda.gov/scalenet/scalenet.htm. Accessed 14 October 2010.
Paik, W.H. 1978. Illustrated Flora and Fauna of Korea, vol. 22, Insecta (VI), Coccoidea. 481 pp. Ministry of Education.

Paik, J.C. 2000. Economic Insects of Korea 6, Homoptera (Coccinea). Insecta Koreana Suppl. 13. 193 pp. National Institute of Agricultural Science and Technology.

Williams, D.J. and D.R. Miller. 2002. Systematic studies on the Antonina crawi Cockerell (Hemiptera: Coccoidea: Pseudococcidae) complex of pest mealybugs. Proceedings of the Entomological Society of Washington 104(4): 896-911. 